\title{
The Development of Students' Social Integration Attitude Through Learning Islamic History in Surakarta
}

\author{
Dr. Baidi, M.Pd \\ Surakarta State Institute for Islamic Studies \\ baidi@iain-surakarta.ac.id
}

\begin{abstract}
The objectives of this research are to know: 1) the effectiveness of the application of inquiry methods compared with the expository method in Islamic history learning to develop students' social integration attitude MAN Surakarta; 2) differences in the influence of Students' interest in Islamic history learning (high, medium and low) in learning Islamic history in order to develop students' social integration attitude MAN Surakarta students; 3) the influence of interaction between the application of methods and students' interest in learning Islamic history in the development of social integration attitude of MAN Surakarta students. This research used experimental method. The population of study were all students of class XI MAN I and II Surakarta. The sampling technique which used was proportional stratified random sampling method for 150 respondents. There were 84 students for the experimental group and 66 students in the control group. Questionnaire about social integration attitudes and interest in Islamic history learning was used as data collection technique in this research. The Instrument validity test was done by using item validity with product moment formula while the instrument reliability test was done by using split half method with product moment formula of Spearman Brown. The data were analyzed using two analytical variants (ANAVA) which determined by multiple comparisan text. The results of research showed; 1) Inquiry learning method was more effective than expository method in learning Islamic history in developing social integration attitude of MAN Surakarta students. 2) Students who have high interest in learning Islamic history had better social integration attitudes than those with moderate or low learning interests. 3) Furthermore, there was a significant interaction and influence between the application of those teaching method (inquiry and expository) and students' interest in learning (high, medium and low) Islamic history to develop the social integration attitude of MAN Surakarta.
\end{abstract}

Keywords- Learning Islamic History; Learning Interest; Teaching Method and Social Integration Attitude.

\section{INTRODUCTION}

Education can be seen as a communication process of knowledge and the formation of comprehensive values to enter complex life (Cohan,
1971) implemented from one generation to the next generation (Fagerlind and Saha, 1983). Through education, human forms the horizondynamic dialectics, because action always requires another human being in coexistence and cooperation (Dick Hartoko, 1990). Therefore, humans need to develop social integration attitudes in common life.

One of the Islamic educational institutions in Indonesia is a madrassa which began to develop in 1915 (Steenbrink, 1986: 165) and which in the curriculum, it contained Islamic history or history (Steenbrink, 1986: 168). History learning in secondary schools does not produce historians, but rather builds students' personalities and mental attitudes (Van der Mulen, 1987). Historical learning forms historical forces and historical awareness or historical mindedness (Kuntawijaya, 1991).

Each field of study which is summarized in the curriculum has construction of achievement of the objectives in National Education, namely the intellectual life of the nation (Freda, Darmana, and Darmanto 1984). History subjects aimed to develop attitudes and personality (Moedjanto, 1998), shaping mental and moral and human dignity (Dick Hatoko, 1990); fostering historical consciousness (Sartono K, 1989). Teaching history is a process of dialogue in understanding the past as a foothold to welcome the future (Orstein and Levins, 1984, Hornby, 1984, Dilthey, 1961). Building a functional understanding for present and future life (Freire, 1984); developing self-ability as an element of social attitudes (Coltham Fines, 1971). As one of the characteristics of Islamic education institution, which called as Madrasah Aliyah (MA) is given subject, namely Islamic history (tarikh). Teaching of Islamic history is influenced by the element of providence (Ballard, 1971), so that between historiography and theology there is a meeting point (Kuntowijaya, 1991). Teaching history is the process of understanding, connecting with the various causes, reasons and consequences of the event (Ibn Khaldun, 1986). History is not just a story of past life, but a ibrah (wisdom) for humans now to live the present and future life (Dianna, 2014). In understanding history, not only objective-empirical historical data, but subjective-normative moral 
messages (Nazaruddin Siddiqi, 1986); Islam (Rosenthal, 1968; 45).

Teaching Islamic history is one of media to understand students about the struggle of Prophet Muhammad and his companions and successors in preaching Islam. The concept of Islamic history is based on the position of man as God's khalifah on the earth, every individual must be conscious to play a role in carrying out his responsibility as a servant of God (Kuntowijaya, 1991), to form historical force and historical mindedness. The birth of religion as a scientific study began to be introduced by Max Muller with the work of "Relegion Wissenschaft" (Abdurrahman, 1984), so that this emerged historicphenomenological approach which developed by William Schmit (Abdurrahman, 1984). Developing a historical awareness of the 'ummah' contained the meaning of 'amar ma'ruf nahi munkar (invoking goodness and forbidding evil) to humanity, then on the other hand man is required to do good to others (Mahzeruddin Siddiqi, 1986).

Social integration is considered a key indicator of environmental adaptation. Social integration involves interpersonal relationship, support, interaction with others and a sense of belonging. Social integrationderived from extracurricular activities, informal relationship with groups of friends and students' interaction with all school residents (Danielle, Hammond \& Candice, 2014). In line with Abdul Manan (2008), social integration consists of three criteria: (a) informal social contact with staff academics, (b) extracurricular activities and (c) peer group interaction. Social integration also affects memory and focus. A person with high social integration will have better memory and focus than someone with low social integration, thus it helps in the process of academic learning as well as learning in the community (Karen, Maria \& Lisa, 2008).

Various factors which influence the development of social integration attitude among other, namely; personal experience, institution, mass media, socioeconomic, political, religion, knowledge and emotion within oneself. Human and society are the two dialectically interacting realities of Dick Hartoko, 1990). The object of social integration attitude in this study was adapted from Robert K. Morton \& Robert A. Naisbeth, 1962) which presented a variety of contemporary social issues. The issue of social integration is a challenge to be faced and resolved. Toynbee in Robert K. Morton \& Robert A. Naisbit (1962), ... has pointed out his history of civilization as a succession of challenge ... .. ". Behavioral forms are not only attitude but they are complex, within a certain extent human behavior is predictable from attitude that arise (Azwar, 1988). The attitude of social integration is formed from the cognition, conformation and affection gained through the study of Islamic history.
In learning Islamic history, teachers have an important role in; presenting information, fosters thinking skills, guiding attitude of students' learning, so that it means teachers who have various skills in implementing learning which is efficient and effective. The role of teachers is represented by the application of applied teaching methods. In the learning process, there are four elements which are very important, namely teachers, students materials, and methods of learning. Method is something which is important in primary and secondary education, it is different than in college because through the maturity of students,they can learn by themselves. Understanding methods is a way of doing or conveying something. Method is acquisition of facts and information which was stressed and to deal mostly with importing subject matters. In class, method is meant to order certain definite results (Lardizabal, 1978; 19).

One of problems of the education world today is the weakness of teaching and learning process (Sanjaya, 2011: 1). In the learning process, students are less encouraged to build concepts, develop thinking skills, explore new understanding and solicit problems. The process of learning in the classroom still emphasizes in memorizing data, information and it is still not meaningful yet in everyday life. It should be more meaningful learning of students to develop concepts by associating the experiences and phenomena encountered (Wisudawati and Sulistyowati, 2014; 44). Therefore, it is necessary to change the learning paradigm from receiving information to produce information. Teachers do not position it as a source of learning, but as a source manager oflearning which train students to think critically. Learning is not merely memorizing data, concepts, formulas, but using data to sharpen thinking skills.

According to the 2013 curriculum,students' learning are encouraged to find their own and transform information meaningfully. Students are subjects who have the ability to actively seek, process, construct and use knowledge in everyday life (Permendikbud number 81 of 2013). In the process of teaching and learning process, ot is necesaary to develop critical thinking skills, analyzing to make choices and draw conclusion (Kurniawati, 2014). Inquiry-based learning is process in which teachers and students engage in learning activities from determining plans, structure and design in learning situation (Hwang, Han Zhuang \& Min Huang, 2013).

The purpose of inquiry learning is to train students to develop students' thinking skills by giving questions about the problems and getting basic answers (Sanjaya, 2012). Teachers provide opportunities to them to learn to think critically, creatively and in discussion. (Ibe, 2013), developing critical thinking and thinking habits (Llewelly, 2013). Inquiry learning is more meaningful because it develops cognitive, affective and psychomotor 
aspects in a balanced way (Hosnan, 2014). Critical thinking means thinking clearly and intelligently,it can be done in various living environments, among others; in class, at work, at home and in the community (Bassham, 2011). Inquiriy learning is done by involving students in investigation, finding concepts and solving problems (Andi \& Ahmadi, 2010). The syntax of inquiry learning consists of formulating the problem, making hypotheses, designing experiments, conducting experiments, analyzing and making conclusion (Triyanto, 2007). In various studies show the superiority of teaching inquiry, among others; 1). It's more effective in improving critical thinking skills than conventional teaching (Triwiyono, 2011), 2). Improving students' critical thinking regardless to differences in residence and local origin (Gay and Howard, 2000), 3). Improving critical thinking skills in learning history and reducing the gap between students in learning history (Kitot, 2010).

Medium method of expository (Exspository method). It means showing or telling, explaning or interpreting. Expository learning strategy as a direct instruction (direct instruction), because teachers explain and conclude directly to students to be understood (Gulo, 2002). The main objective which achieved by the application of expository methods is intellectual ability, whereas personal and social abilities are not yet been established (Nunuk and Agung, 2012). Expository teaching is less precise when the goal to be achieved is the discovery of new concepts as well as deep dig in a particular problem. Basically the expository method is a companion of all teaching. The objective of this method is to explain by constructing narratives and description to provide information to arouse attention and stimulate imagination-thinking. The main purpose of this method is to provide a broad overview of the guidance on the subject material (Lardizabal, 1978, 118-122).

\section{RESEARCH METHOD}

This research used experiment method because the output of this research will confirm the question of research above and the causal relation among variables which being analyzed. Respondents were devided in two groups, namely; experiment group and control group. The population of this research were the students of class XI of Islamic Senior High School (Madrasah Aliyah) in Surakarta for Academic year $2016 / 2017$. The sample were taken by proportional cluster random sampling technique. There were 150 respondents consisting 84 students for experiment group and 66 students for control group. Questionaire about their interest in learning Islamic History and social integrated attitude was also used as the data collecting technique. The validity of questionnaire was tested by using item validity with product moment formula. Realistically questionnaire were tested by using alpha formula from Cronbach. The reliability of validity coefficient were attained at the sum of; 0,$825 ; 0.835$. The data were analyzed by the two way variant analytical technique (ANAVA) and continued with the Multiple Comparision Test. Before the hypothetical testing was performed, the normally and homogenity value must be tested.

\section{RESULTS OF RESEARCH AND DISCUSSION}

The data of research was tested using ANAVA with 3 $\mathrm{X} 2$ design which determined with scheefe test to know the highest level of significance group. The analysis of ANAVA model with $3 \times 2$ design to know the influence and interaction of each variant. First, to analyze whether there were significance differences between inquiry and expository learning models in Islamic history learning to improve students' social integrated attitude. Second, to analysis whether there were significance differences between learning interest (high, middle and low) toward Islamic history learning in order to improve students' social integrated attitude. Third, to analysis whether there was interaction correlation between learning models (inquiry, expository) and learning interest student's (high, middle, low) toward Islamic history learning in order to improve social integrated attitude of students.

Based on the data calculation using of SPSS Program, the summary of ANAVA results are shown in this Table- below:

TABLE 1. THE SUMARY ANALYSIS OF VARIAN DEVELOPMENT OF STUDENTS' SOCIAL INTEGRATION ATTITUDE THROUGH ISLAMIC HISTORY LEARNING VIEWED FROM LEARNING INTEREST AND THE APPLICATION OF LEARNING METHOD IN MADRASAH ALIYAH SURAKARTA JAWA TENGAH, INDONESIA 2017/2018

\begin{tabular}{|l|c|c|c|c|c|c|}
\hline e source of Varian & \multicolumn{1}{c|}{$\mathrm{db}$} & \multicolumn{1}{c|}{ JK } & MK & Fh & Ft & Ket \\
\hline Antar (A) & 2 & 9852.722 & 2562375 & 67413.36 & 18,51 & h $>$ Ft \\
\hline Antar (B) & 1 & 192.55 & 5154090 & 135598.6 & 18,51 & h $>$ Ft \\
\hline veen AB (AB) & 2 & 3372.92 & 31686.46 & 8333.6371 & 7,71 & h $>$ Ft \\
\hline Inside & 148 & 625.465 & 38.0099 & & & \\
\hline Total (tot) & 149 & 18043.7 & & & & \\
\hline
\end{tabular}

\section{HYPOTHESIS OF RESEARCH}

There is difference of influence in applying the inquiri method and expository method to develop social integration attitude of students in learning of Islamic history, students of class XI semester I Madrasah Aliyah Negeri Surakarta Academic year 2016/2017.

From the ANOVA analysis, the result which obtained, F count 135598,6> F table 18,51. means that the hypothesis (Ha) was accepted and the statistical hypothesis was rejected. Thus, it can be 
concluded that students who have learned the history of Islam by using inquiri method have a better attitude of social integration than those who use expository method.

In line with what has expressed by Setiawan (2012: 303) that the results of students' learning using inquiry learning method is better than the students' learning outcome which use conventional learning model. Guided inquiry method appropriately used in MA / SMA because students tend to be less independent and still need advice and gestures from teachers (Rocmatika, Harlita \& Prayitno, 2012). The learning model can improve the skills, participation and interest of students' learning process (Wulaningsih, Prayitno \& Probosari, 2012). The positive influence of inquiry learning model is caused by several factors, including: 1) learning implementation, 2) the problems presented can arouse students' interest and curiosity, 3) practicum tools which support learning activities, and 4) the chance of students to communicate results of discussion (Kristanto \& Susilo, 2015). It indicates that the inquiry method has a positive impact on teaching and learning activities, It can increase students' activity during learning, and can increase students' interest in following the learning process. In line with Upasana Singh (2013), that teacher's role in classis vital to create technology-based instruction and encourage student-centered learning to adapt individual learning styles to be optimum application-based learning.

The attitude of social integration arises because of stimulus. It can be formed from the inquiry process which enables students to be actively involved in the acquisition of concepts so that to enhance the curiosity, communication and integration among students (Maikristina et al., 2013), and can foster scientific attitude such as meticulous, responsible, disciplined, and cooperation (Hapsari et al., 2012). The formation of an attitude is much influenced by the social and cultural environment, such as family, school, norm, religion, and custom. Attitude growz and flourishes in certain social bases, for example: economics, politics, religion and so on (Atmaja, Lasamawan \& Natajaya, 2014: 7). Sabine \& Schmidt (2009), states that enabling the learning environment with students and social integration will have a positive effect on the progress of learning outcome and students' retention. The development of social integration attitudes is very important to grow especially for the people in Surakarta with various ethnic and religious background, resulting in vulnerability comflict among the community. The study of Islamic history is also an indicator of religious aspect which given in curriculum to establish better social integration attitude of students. The study of Islamic history which given to santri in Java influences their daily social integration attitude, including the tradition that still practiced and preserved up to now, It is the result of the relics of the early scholars, by studying the santris who try to follow the social pattern which is done by the scholars and still preserved until now (Djoko Suryo, 2000).

The diversity of Surakarta community lasts from the 17 th century. While the radicalization that emerged in the 20th century was a challenge for the sustainability of pluralistic society. Mediation and cross-ethnic and religious communication need to be built both in schools and communities to control social conflicts into social integration attitudes (Zainudin Fauroni \& Dwi Purwanto, 2006). Disturbance of religious intolerance can be threatening at any time due to the emergence of new generations born out of historical experience and the base of different worldviews. So it needs to develop social integration attitude in various educational institutions including Madrasah Aliyah through learning Islamic history. The growing attitude of social integration in the education environment is very desirable by the Government of Surakarta. Even the vision of Surakarta City Government is to build a social harmony to realize Surakarta as a cultural city and student city. Basically the attitude of social integration is formed from social behavior based on Islamic historical values and religion especially amar ma'ruf nahi munkar.

Judging from the configuration of religious life, Surakarta has a strong Islamic and Christian power composition. The clash between the two occurred when the issue of humiliation or Christianization emerged.Differences in orientation of any kind can be placed on the value of compliance and wisdom, because the principles in Islam are tethered to the amar ma'ruf nahi munkar. The principle of value is a reference in living socio-cultural, economic and political life (Abudin Nata, 2004). To maintain social integration needs to develop social relationships that serve as a binder of differences and provide a space for dialogue. Religious dialogue is a necessity in a multi-religious society. In the context of plural society, religious dialogue is an effective form of communication towards social integration. Religious dialogue should take into account that there are limits that must be preserved in any religion. The region lies in the transnational and unspoken ideal of divine ideal or truth. Conversely, interreligious dialogue basically speaks of truth, critical, worldly that is open to compromise (Moh Sobary, 1994).

Sabine \& Schmidt (2009) suggests various factors that promote social integration, namely: 1) a cultural flavor that encourages the growth of nationalism; 2) tolerance toward other religions based on contextual relativism; 3) the emergence of social mechanisms that are ready to foster subjective and pluralistic social integration. The development of social 
integration attitude in Surakarta society is also good. This is an evident in the assimilation between the majority Muslim citizens with Christians, Catholics, Hindus, Buddhists and Kong $\mathrm{Hu}$ Chu during the election of Catholic-elected Mayors. Muslims in Surakarta did not cause conflict of division but continue to support government work based on the principle of Bhineka Tunggal Ika. It can happen because inter-religious dialogue is good so that social life can be directed toward creating harmonious life, tolerance, openness, mutual respect, understanding, and integration between various religion (Burhanuddin Daya, 2004).

2.There is a difference of influence between learning interest (high, medium and low) of Islamic history on the development of social integration of students' attitude of class XI students of first semester,public Madrasah Aliyah Surakarta, Academic Year 2016/2017.

Based on the ANOVA statistical analysis above, it was obtained F count 67413,36> Ftabel 18,51. It means that accepted hypothesis (Ha) and the statistical hypothesis were rejected. Thus, it can be concluded that the average score of social integration attitude of students differs from those who have learning interest (high, medium and low) in learning Islamic history. It means that the social integration attitude of students with higher interests are higher than those who were moderate and had low interest. The higher the interest in learning Islamic history, the higher the students' social integration attitude. In line with that Abdul Manan (2007), it is ecplained that the higher interest of students in the subjects will increase the integration of individuals in the social environment and increase students' persistence in completion of learning. Interest in learning process has a strategic role in improving attitude.High interest in something will give a high boost to reach satisfaction (Hurlock, 1980). When satisfaction declines, interest also decreases, so that interest becomes a very important factor. Interest shows the ability and willingness to provide stimulation whichencourages a person's curiosity and shows a high performance to achieve success.

Interest is a function of soul to be able to achieve something. In carrying out the functions of interest, it is closely related to thought and feeling that will have an effect on one's attitude (Yessy, 2015: 10). Students who have a high interest in learning Islamic history, will be enthusiastic to follow the material and more actively find out information about Islamic history. This will shape students' social integration attitude which is basically the result of the process of socializing and interacting with environment. The attitude of social integration is the embodiment of one's thought, feeling and judgment on the object, based on knowledge, understanding, opinion, belief and ideas to produce a tendency to act (Yayat, 2009: 4). It will encourage students to tend to have an attitude of social integration in accordance with what is taught in Islamic history.

3. There is influence-interaction between the application of teaching methods with the interest of learning Islamic history on the development of social integration attitude of students of class XI semester I Madrasah Aliyah Negeri Surakarta Academic Year 2016/2017.

From the result of ANOVA analysis, it was obtained the value of Fhitung 833, 6371> F table 7.71. It means the accepted hypothesis (Ha) was accepted and the statistical hypothesis (Ho) was rejected. The conclusion provides an understanding that there is an interaction between teaching methods and the interest of learning Islamic history on the development of social integration attitude. To know every correlation between teaching method and interest in learning history of Islam with students' social integration attitude, then it waa tested by Scheefe Method, with the result were as follows:

1. The average score of social integration attitude of students using inquiry teaching method with high learning interest was 199.4872 with a standard deviation of 12.9734. While those with moderate interest was 191,5385 with standard deviation was 13.46037. Thus there was a difference between the average score of those two groups, 7.9487

2. The average score of social integration attitude which using inquiry teaching method with high learning interest was 199.4872 with a standard deviation of 12.9734. While having low interest in learning was 186,3684 with deviation standard 10,54093 . Thus, there was a difference between the average score of both groups as much as 13.1188.

3. The mean score of social integration attitude of students using inquiry teaching method with moderate learning interest was 191.5385 , with a standard deviation of 13.46037 . While students with low interest was 186.3684 with the standard deviation value of 10.54093 . It can be said that there is a difference in the mean score between the two groups of 5.1701.

4. The mean score of social integration attitude of students using expository method with high learning interest was 185.4688 , with a standard deviation value of 24.28193. While those with moderate learning interest was 153,1739 with the deviation standard 26,81867. Thus, there was a difference between the average score of two groups 32.2949. 
5. The mean score of students' social integration attitude using expository method with high learning interest was 185,4688 , with standard deviation as much as 24,28193 . While students with low learning interest was 138.7273 with a standard deviation of 27.64811. There was a difference between the average score of two groups as much as 46.71415 .

6. The average score of students' social integration attitude using expository method with moderate learning interest was 153,1739 with a standard deviation value was 26.81867. For those who have low learning interest was 138.7273 with a standard deviation of 27.64811. Thus, there was a difference between the average score of those two groups of 14.4466 .

7. There was a very significant difference $(\mathrm{Fh}=$ $67413,36>\mathrm{Ft}=18,51)$ in students' social integration attitude who have interest in learning Islamic history (high premises 193,169 with standard deviation of 20,04565 , while with score 177,8571 with standard deviation 31.21231 and low with scores 175, 6333 with stadnar deviation 33.88671). Thus, the attitude of social integration between students who have interest in learning Islamic history (high, medium and low) showed that there was a very high difference. It can be concluded that the higher the learning interest of Islamic history, the higher the social integration attitude score.

8. There was a very significant difference $(\mathrm{Fh}=$ 135598.6 $\mathrm{Ft}=18.51)$ in term of students' social integration attitude between those who use teaching method (inquiry method with score 192,4647 and with standard deviation 179.3751 , expository method with score 166, 4242 with standard deviation value 132,3027). Thus, the attitude of social intimacy between students who use teaching methods (inquiry, ekspository) indicated that there was a very high difference. It can be concluded that the inquiry method in teaching Islamic history further improved the student's social integration attitude instead od the expository method.

The next finding in this research showed that there was interaction of influence between learning interest and teaching method to the development of social integration attitude of MAN Surakarta students. In this case, the teacher has an important role to increase their interest in learning through various things, among other, such as; giving a full explanation of the concept of Islamic history, selecting material whch suits the needs and levels of development, providing a real meaningful experience, reducing and even eliminating negative stereotypes about Islamic history.

Various studies showed that the use of inquiry method had results in term of significant improvement in the cognitive, affective and psychomotor aspects. From the results of this research, it can be concluded that the average score of students' social integration attitude of the experimental and control group had a considerable difference. The summary of their results can be seen in table-3 below:

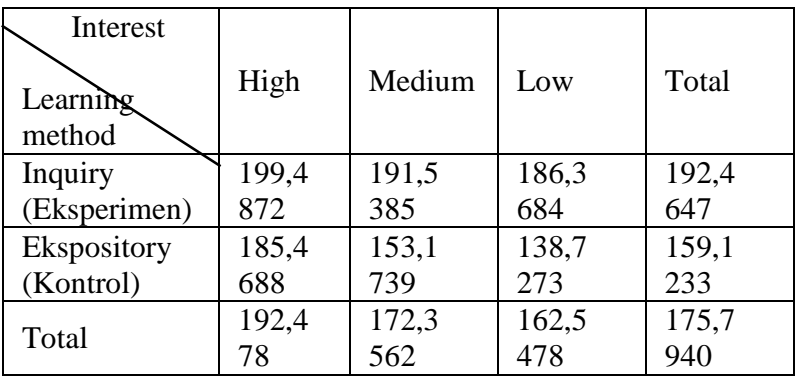

Differences can occur because the teachinglearning process using the inquiry method provides a wider opportunity to develop critical, analytical, and critical thinking skills

An answer to the question posed (Hosnan, 2014). Inquiri's learning emphasizes on students' critical thinking, analytical to gain a learning experience, thereby it means developing social attitude through learning Islamic history. Because the growth of social integration attitudes is determined by knowledge, experience, and perception of a particular object. Knowledge, experience gained through observation as well as a critical attitude to historical phenomena and associated with current reality, so that the choice of choice, the tendency of action of students. In learning with inquiry method, students have the opportunity to ask questions based on phenomena obtained from observation with teacher guidance, while in class with expository method, questions were asked by teacher to students.

Inquiry learning yields higher scores than exposures due to several factors including: 1) studentcentered inquiry method provides opportunities for intellectual, emotional and skill self-potential development; 2) emphasize maximum student activity to get an answer to a problem so as to encourage a better attitude growth; 3) provide immediate experience so that the meaning of learning is made; 4) mobilize all abilities, thought, emotion and physical in learning, so that cultivate the curiosity to get answer to the problems faced. Levy, Aiyegbayot \& Little (2009). The use of active learning in the classroom, an increase in personal and social competence as well as general knowledge including improving students' social integration attitude (Armburster, Patel, Johson \& Weis, 2009).

Theoretically, empirical education experts stated that there is no learning process without interest. 
Various evidences indicate that interest is a significant factor in achieving successful learning. In Pavlovian Conditioning theory, he explains how important the role of interest in the context of all behavior. The concept of classical conditioning is shown how important the role of interest in teaching and learning process, as the following phrase: ... motivation is probably more dispensable for meaningfull acceptance of learning ... culinary attitude (Ausabel, Novak, Hanesian, 1978, p.400).

\section{CONCLUSION AND SUGGESTION}

The result of data analysis above showed that in general, there were differences in attitude of students social integration of MAN Surakarta between those who used inquiry method and expository in leaening of Islamic history or between those who have interest in learning (high, medium and low). There were also interaction between the application of teaching method of perception and interest in learning Islamic history on the attitude of social integration of students MAN Surakarta.

Based on the conclusion of the research results, suggestion which may arise as follows:

1. For MAN Surakarta institution itself, It is necessary to strengthen the position and role of Islamic history in the context of education in the institution, so that students' interest will grow in studying the history of Islam among students.

2. For educators, It needs to develop the use of inquiry learning methods, with an active and enjoyable learning process so that the material can be delivered effectively so that it can be applied well by the students.

3. For MAN Surakarta institution, the need to develop a fun learning atmosphere so that will increase the interest of students in general, including in learning Islamic history, involving teachers and students.

4. For some teachers of Islamic history subjects, they should make improvement thorough both in term of learning method, teaching and learning process so that the interest of students in learning Islamic history could increase and would affect on the development of their social attitude.

5. It needs for further research to see other factors which can influence the development of social attitude of students, such as learning media, learning models, all of them can provide information as well as a better learning experience.

\section{REFERENCES}

[1] Abdul Mannan. (2007). Student Attrition And Academic And Social Integration: Application of tinto's Model at the University of Papua New Guinea. Higher Education 53: 147-165, DOI 10.1007/s10734-005-2496-y

[2] Abdurrahman. (1984). Pembahasan Sejarah Islam di Indonesia Tinjauan Umum: Muker Sejarah VIII Tanggal 17-19 Desember 1984.

[3] Abudin Nata. (2004). Pendidikan Islam: Periode Klasik. Jakarta: Raja Grafindo Persada.

[4] Armbruster, P, Patel M, Johson E \& Weiss, M. (2009). Active Learning Student Centered Pedagogy Improve Student Attitude and Performance in Introductory Biology. GBE Life Science Education 8.203213.doi:10.11871cbe.09-03-0025

[5] Ausebel. David.P, Novak. Joseph, Hanesian Helen. (1978). Educational Psychology: A Cognitive View. New York: Holt Rinehart and Winston.

[6] Asih Widi \& Eka Sulistyowati. (2014). Metodologi Pembelajaran IPA. Jakarta: Bumi Aksara.

[7] Burhanudi Daya. (2004). Agama Dialogis Merenda Dialektika Idealita dan Realita Hubungan Antar Agama. Yogyakarta: Pustaka Pelajar.

[8] Cohan, YA. (1971). The Shaping of mens mind adaptation of imperative of culture dalam Max (Ed.) Antrophologycal perspective of education (p. 143-168). New York: Basic Book.

[9] Danielle E, Hammond \& Candice Shoemaker. (2014). Academic And Social Integration of College of Agriculture Master's Students in Campus Based, Online and Mixed Program. NACTA Journal, Kansas State University Manhattan, KS

[10] Didik Setiawan, I.G.P.A, Buditjahjanto. (2013). Pengaruh Metode Pembelajaran Inkuiri Terhadap Ketuntasan Hasil Belajar Siswa Di SMKN 3 Buduran Sidoarjo. Jurnal Pendidikan Teknik Elektro, vol. 2, No. 1 Tahun 2013.

[11] Djoko Suryo. 2000. Tradisi Santri Dalam Historiografi Jawa: Pengaruh Islam di Jawa. Diluncurkan Pada Seminar Pengaruh Islam Terhadap Budaya Jawa, 31 Nopember 2000).

[12] Fauroni Zainudin, Dwi Purwanto. (2006). Radikalisme Keagamaan dan Perubahan Sosial. Penelitian Tidak Diterbitkan; UMS

[13] Figerlin I \& Saha G. C. C. (1983). Education and national development. New York: Pergamon Press.

[14] Freda, NRH, Darmono, SS \& Darmanto, Y. (1984). Manusia Seutuhnya, Beberapa Gagasan. Semarang: Badan Penerbit Universitas Diponegoro.

[15] Freire, Paulo. (1984). Pedagogy of the Oppreised. New York: The Continue Publishing Corporation.

[16] Gay, L. R. \& Howard (2000). Educational Research. Ohio: A Beel \& Howell Compqny.

[17] Gulo, W. (2002). Metodologi Penelitian. Jakarta: Grasindo.

[18] Gwo Jen Hwang, Po Han Wu, Ya Yen Zhuang \& Yueh Min Huang. (2013). Effects of The Inquiry-Based Mobile Learning Model on The Cognitive Load And Learning Achievement of Students. Interactive Learning Environment Vol. 21, No. 4, 338-354.

[19] Hapsari, D. P., Sudarisman, S., Marjono. (2012). Pengaruh Model Inkuiri Terbimbingn Dengan Model Diagram $V$ (Vee) Dalam Pembelajaran Biologi Terhadap Kemampuan Berpikir Kritis dan Hasil Belajar Siswa. Jurnal (Online) 4 (2014): 16-28.

[20] Hartoko, Dick J. (1990). Memanusiakan Manusia Muda Tinjauan Pendidikan Humaniora. Jogjakarta: Kanisius.

[21] Hosnan, M. (2014). Pendekatan saintifik dan Konstektual Dalam Pembelajaran Abad 21. Bogor: Ghalia Indonesia.

[22] Hurlock, Elizabeth B. (1980). Psikologi Perkembangan: Suatu Pendekatan Sepanjang Rentang Kehidupan. Jakarta: Erlangga. 
[23] Ibe, Helen, N. H. (2013). Effects of Guided Inquiry and Expository Teaching method in Senior Secondary School Student's Performance in Biology in Imo State. Journal of Education Reserch of Behaviour Science (Online) vol 2 (4)-1051-057.

[24] Ibnu Khaldun. (1986). Muqaddimah, diterjemahkan Ahmadie Thoha. Jakarta: Pustaka Firdaus.

[25] Johson D, Johson RA Smith. (1991). Cooperative Learning Increasing College Faculty Intructional Productivity (V.20). Washington DC: The George Washington University, Graduate School of Education and Human Development.

[26] Kitot, A.K.A., Ahmad AR, Serman AA. (2010). The Effectiveness of Inquiry Teaching Enhancing Students in Critical Thinking : Proceeding Social in Behavior Science 7 ( C ) 264-273.

[27] Krech, D., Crutchfield, R. S. \& Ballachey, E. (1962). Individual in Society.

[28] Kuntawijaya (1991). Paradigma Islam: Interpretasi untuk Aksi. Penerbit: Mizan.

[29] Kurniawati iD, Wartono, diantoro M. (2014). Pengaruh Pembelajaran Inquiry Terbimbing Kategori Perr Introduction Terhadap Penguasaan Konsep Dan Kemampuan Berpikir Kritis siswa. Jurnal Pendidikan Fisika Indonesia, 10 (2014) 36-46.

[30] Lewellyn D. (2013). Teaching High Scool Science Trhough Inquiry and Argumentation ( $\mathrm{Zud}$ ed.). California: Corwin.

[31] Maikristina, N., I Wayan Dasna, I. W., Sulistina, O. (2013). Pengaruh Penggunaan Model Pembelajaran Inkuiri Terbimbing Terhadap Hasisl Belajar dan Keterampilan Proses Sains Siswa Kelas XI IPA SMAN 3 Malang Pada Materi Hidrolis Garam.Jurnal(Online),(http://jurnal-online.um.ac.id)

[32] Moedjanto. (1998). Indonesia Abad ke-20 dari Kebangkitan Nasional sampai Linggarjati. Yogyakarta: Kanisius.

[33] Moh Sobary. (1994). Merombak Primodialisme dalam Agama, dalam Spriritualitas Agama dan Aspirasi Rakyat. Yogyakarta: Institute Dian.

[34] Nunuk Suryani \& Leo Agung. (2012). Startegi Belajar Mengjar. Yogyakarta: Ombak.

[35] P. Levy, Aiyegbayot \& S. Little. (2009). Designing for Inquiry-Based Learning With The Learning Activity Management System. Journal of Computer Assisted Learning, 25:238-251, DOI: $10.1111 / \mathrm{j} .1365-$ 2729.2008.00309.x

[36] Risqi Rahman \& Samsul Maarif. (2014). Pengaruh Penggunaan Metode Discovery Terhadap Kemampuan Analogi Matematis Siswa SMK Al-Ikhsan Pamarican Kabupaten Ciamis Jawa Barat. Jurnal Ilmiah Program
Studi Matematika STKIP Siliwangi Bandung, vol 3, No. 1.

[37] Rosenthal, F. (1968). Muslim Historiografi. Leiden: E.J. Bill.

[38] Sabine E Severiens \& Henk G. Schmidt. (2009). Academic And Social Integration And Study Progress In Problem Based Leaning. High Educ 58:59-69 DOI 10.1007/s10734-008-9181-x

[39] Sanjaya w. (2011). Strategi pembelajaran Berorientasi standar Proses Pendidikan. Jakarta: Kencana.

[40] Sartono, K. (1989). Pemilihan dan Perkembangan Historiografi Indonesia, Suatu Alternatif. Jakarta: Gramedia.

[41] Siddiqi, M. (1986). Konsep Al-Qur' an Tentang Sejarah. Jakarta: Pustaka Firdaus.

[42] Steenbrink Karel A. (1986). Pesantren, Madrasah, Sekolah: Pendidikan Islam Dalam Kurun Moderen. Jakarta: LP3ES.

[43] Temos, MH. (2013). The Effect of The Classroom Performance System on Student Participation Attandance and Achivement. International Journal of Teaching and Learning in Higher Education, 25(1) 6678.

[44] Triwoyono (2011). Program Pembelajaran Fisika Menggunakan Metode Eksperimen Terbimbing untuk Meningkatkan Keterampilan Berpikir Kritis. Jurnal Pendidikan Fisika Indonesia (online) 7. 80-83.

[45] Triyanto. (20007). Model-Model Pembelajaran Inovatif Berorientasi Konstruktivistif. Jakarta: Balai Pustaka.

[46] Upasana Singh. (2013). Technology Integration In Teacher Education: An Influsion Or A Delusion?. Research World, Journal of Arts, Science \& Commerce, E-ISSN 2231-4172.

[47] Van Der Meulen, W. J. (1987). Indonesia di Ambang Sejarah. Yogyakarta: Kanisisus.

[48] Wulaningsih S, Prayitno \& Probosari. (2012). Pengaruh Model Pembelajaran Inquiry Terbimbing Terhadap Keterampilan Proses Sains Ditinjau dari Kemampuan Siswa SMA Surakarta. Jurnal Pendidikan Biologi Vol. 4 No. 2, 33-43.

[49] Yayat Suharyat. (2009). Hubungan Antara Sikap, Minat Dan Perilaku Manusia. Region Vol I, No. 2 Juni 2009.

[50] Yono Edy Kristatnto \& Herawati Susilo. (2015). Pengaruh Model Pembelajaran Inkuiri Terbimbing terhadap Kemampuan Berpikir Kritis dan Hasil Belajar IPA Siswa Kelas VII SMP. Jurnal Pendidikan Dan Pembelajaran, Vol. 22 No. 2, Oktober 2015.

[51] Zahra \& Nermin. (2009). The Effect of Guide Inquiri Method on Teachers Saince Theaching Self Efficacy Beliefes. Journal of Turkish Science Education Vol. 6. 